\title{
Financial and Economic Support of the Organization of the Educational Process
}

\author{
Submitted $10 / 05 / 20,1^{\text {st }}$ revision $16 / 09 / 20,2^{\text {nd }}$ revision $21 / 07 / 20$, accepted $15 / 08 / 20$ \\ Irina V. Zastrozhnikova ${ }^{1}$, Nadiia V. Datsii ${ }^{2}$, Nelya M. Filyanina ${ }^{3}$, \\ Petro S. Oleshko ${ }^{4}$, Nataliia M. Shkvorchenko ${ }^{5}$, Liliia A. Martynets ${ }^{6}$ \\ Abstract:
}

Purpose: The main objective of this article is to analyze trends in funding educational institutions (EI) and to assess the effectiveness of the distribution of government expenditures on primary education at the macro- and micro levels.

Design/Methodology/Approach: Based on the analysis and synthesis of information from countries' analytical reports, statistical databases and scientific literature, the basic entities involved in the formation, management and distribution of education expenditures in different countries at different levels have been considered, as well as an analysis of the interaction between them has been conducted. Main mechanisms of distribution of expenditures for the educational process in different countries have been observed.

Findings: The different approaches used in the distribution of expenditures have been highlighted and the most effective methods of conducting the policy of financing the system of education among European countries have been identified. The basic factors have been outlined that need to be taken into account when formulating funding formulas that can be adjusted to support the goals of policies aimed at improving the efficiency, equity and quality of education. Possible options for financial and economic support have been considered.

Practical Implications: A model of a decentralized management system for financial and economic support of the educational process based on foreign experience has been proposed to ensure the implementation of effective mechanisms for financing education.

Originality/Value: The study emphasizes that the formation of an effective decentralized system of financing EIs should be implemented in parallel with an effective internal system of financial resources management.

Keywords: Financing mechanism, educational process, system of education. JEL Codes: A1, B1. Article Type: Research article.

\footnotetext{
${ }^{I}$ Associate Professor, Dmytro Motornyi Tavria State Agrotechnological University, Melitopol, Ukraine, E-mail: irenazast@gmail.com

${ }^{2}$ Professor, Zhytomyr National Agroecological University, Zhytomyr, Ukraine,

E-mail: rvps@i.ua

${ }^{3}$ Associate Professor National University of Pharmacy, Kharkiv, Ukraine,

E-mail: nellya-filyanina@hotmail.com

${ }^{4}$ Professor, Central Institute of Postgraduate Pedagogical Education, University of Education Management of the National Academy of Pedagogical Sciences of Ukraine, Kyiv, Ukraine, E-mail: Oleshko.ippo@gmail.com

${ }_{5}^{5}$ Associate Professor, International Humanitarian University, Odesa, Ukraine,

E-mail: nikolette@ukr.net

${ }^{6}$ Associate Professor, Vasyl' Stus Donetsk National University, Vinnytsia, Ukraine,

E-mail: liliamart7@gmail.com
} 


\section{Introduction}

Quality education is a key factor in improving economic efficiency and social justice since it strengthens overall productivity and intellectual flexibility of the workforce. In addition, scientists note that education plays a key role in promoting the development of advanced technologies (Stevens and Weale 2003). Technology mastering, in turn, depends on investment in education, in particular, and investment in human capital, in general. In addition, studies of Lee (1995) indicate that basic education provides greater social benefits than personal ones.

Taking into consideration the resources' shortage, governments should pay attention to developing effective mechanisms for the use and allocation of resources, along with improving transparency, accountability and active community's participation. From this perspective, this study will assess the effectiveness of financial and economic support of the educational process in advanced countries of Europe and Ukraine. To achieve the goal outlined it is necessary to:

1. Analyze the volume and sources of education funding in the studied EU countries.

2. Describe the experience of European countries in forming an effective mechanism for the distribution of financial support for EIs.

3. Determine the dependence between the amount of funding for primary education and the level of quality of education.

4. Describe the main shortcomings and formulate proposals for improving the system of primary education in Ukraine based on the generalized experience of European countries.

\section{Literature Review}

The United Nations (n./d.) report states that universal primary education is a fundamentally important aspect of both individual and global development. The importance of basic education is declared by the post-2015 development program of the UN initiative "Education for All" (UNESCO, 2015b). Hausmann, Rodrik and Velasco (2006) have concluded that the reorientation of development policy in the world basically takes place - from encouraging savings and capital accumulation to increasing human capital by improving the quality of education. Due to the reduction of budget expenditures on education both at the national and international levels, the restriction of funding for educational projects has reached a critical point, which has led to the need to find innovative solutions for financing the system of education.

The data provided in the UNESCO (2015) indicate that basic education is underfunded for 26 million USD. In most developing countries, the need for basic education became more widely recognized only after the proclamation of the Universal Declaration of Human Rights in 1948. Winthrop (2015) notes that the gap between advanced and developing countries is 100 years; more than 1,6 billion 
people from developing countries will need more than 85 years to reach the level of education that advanced countries have at present time.

To address this discrepancy, numerous intergovernmental organizations, such as United Nations Children's Fund (UNICEF) and United Nations Educational, Scientific and Cultural Organization (UNESCO), are focusing their efforts mainly on the education of children in developing countries. In order for every child to receive a quality education at the primary, elementary and lower levels by 2030, at least 22 50 billion US dollars per year are needed. In studies Wolff (2015) and Wolff, Baumol and Saini (2014), regarding the analysis of the ratio of education costs and students' performance among OECD countries, it has been concluded that funding of the system of education costs and its volume increases annually.

Studies, conducted at the macro level (UNESCO, 2015), indicate that although in absolute terms education funding has increased, in relative terms - it has decreased. Therefore, the need to attract innovative methods of financing education is on the agenda around the world. Both new mechanisms for using available funds in innovative way and the search for completely new alternative sources of funding are considered in order to increase the efficiency of education funding (Bellinger, Terway and Burnett, 2016). A number of such scholars, as Terway (2017), Burnett and Bermingham (2010), have studied the development of education innovative funding, along with other sectors such as health care, agriculture, and food security, as well as climate, environment and energy is considered less promising, as education requires long-term investment and is less profitable for investors.

\section{Research Methodology}

In order to understand the changes trends in education funding and their implications at the national level of different countries, the study has been conducted solely on the basis of analysis of secondary data obtained from official reports and statistics of the World Bank, UNESCO, OECD, European Commission, etc. The benchmarking methodology has been applied in the research, which is used to analyze the management of complex social-economic systems, such, as: the system of education, as a modern highly effective way to analyze the situation, level of development and forecasting of possible results from introduction of mechanisms of financial and economic maintenance of the organization of educational process under conditions of use of European countries' best practices.

The study has been conducted by combining methods of analysis and synthesis based on theoretical analysis of countries' surveys. The academic paper involves three main directions: analytical direction, case study direction and synthesis of the obtained results. At the first stage, information was collected on the main features of education financing policy based on evidence from international data, research and analysis. In the analytical part, literature reviews and evaluation of data from countries' reports were conducted to analyze the factors influencing the use and 
distribution of resources in educational systems. The best, reference models for the distribution of education funding among the studied countries were identified by using case-study and benchmarking methods.

\section{Empirical Findings}

According to the World Bank (2018) financial security is one of the main factors determining the success of reforming. According to most indicators, the level of government expenditures on education in Ukraine is high, although it has decreased slightly in recent years. Budget funding for education decreased from 7,2\% of GDP in 2013 to $6,0 \%$ in 2017 (from $21 \%$ to $15 \%$ of total government expenditures). Despite the special situation in Ukraine (World bank, 2018) in comparison with other countries, the Law of Ukraine "On Education" (Article 78) obliges the state to allocate funds for education in the amount of not less than 7 percent of gross domestic product, which potentially weakens the desire to increase expenditures' efficiency.

In high-income countries, as well as in Ukraine, education is funded by public funds, which are accumulated from domestic revenues, taxes and fees. In 2016, EU countries surveyed spent just over 3\% of GDP on education (OECD, 2019). Whereas in 2018, funding of education in EU increased significantly and amounted to 4,6\% (average indicator in EU). The following countries were among the leaders on the level of education funding, namely: Norway $(5,4 \%)$, Belgium $(6,2 \%)$, Iceland $(7,3 \%)$, Finland (5,5\%), Sweden (6,9\%) and Denmark (6,4\%), Estonia $(6,2 \%)$, Latvia $(5,8 \%)$. The total education expenditures of these countries exceed EU average indicator. All these countries have a steady trend towards a high level of education funding, the same trend was observed as of 2016. Only two countries have significantly increased the share of expenditures on education, Estonia (to 4,4\% in 2016) and Latvia (4,2\% in 2016). The search for ways to ensure the effective distribution of education funding is a key challenge for governments, forasmuch as long-term spending on education is increasing as well as the rise in price of educational services among other goods and services (De Witte and López-Torres, 2017).

However, an increase in funding does not always lead to an increase in the level of education, which is critical for the country's economic success. For many years, researchers have focused on the positive impact of the number of EIs and the duration of education for economic growth (Barro, 1991; Mankiw, Romer and Weil, 1992), however, currently it is clear that the quality of education should be the determining factor, that is, the level of students' performance. Based on the conducted study of education quality indicators and their strengths and weaknesses, the World Bank has proposed its own Harmonized Learning Outcomes (HLOs), which are the basis for creating a global database to assess the quality of education worldwide. We have used the capabilities of this database for further analysis of the studied countries (Our World in Data, 2019). 
According to the study, the top five world leaders in the quality of education include Singapore (619), South Korea (607), Hong Kong (605), Taiwan (597), Japan (590). Among the studied European countries, Liechtenstein (557), Estonia (542), and Ireland (535) have the highest rate (HLO). According to data of the World Bank, the best dynamics in the development and improvement of the quality of education during 1980-2015 are demonstrated by such European countries, as Finland, Luxembourg and Sweden with growth of $16 \%, 11 \%$ and $11 \%$, respectively. It can be concluded that the amount of allocated funds is not a determining factor in the level of quality of education in the country, consequently, it is advisable to conduct an expanded analysis of the financing mechanisms of the reference countries' system of primary education, taking into account these features in the formation of education financing policy in developing countries such, as Ukraine.

There are four main approaches to funds' allocation (Levačić, 2008; OECD, 2012), administrative, increase in expenses based on the costs of previous periods, competitive, and formula-based.

Most Western countries use a formula-based approach. Ukraine, with the reform of the education system, has also introduced this approach. In order to analyze the mechanisms of funding distribution in the system of education, we will choose the countries with the highest level of education, but different amounts of funding as in Estonia, Belgium and Lithuania, and consider the mechanism of funding and distribution of expenditures in these countries

In the Flemish and French communities of Belgium (Nusche, Miron, Santiago and Teese, 2015), the basic factors influencing the mechanisms for allocating and distributing targeted grants are the social-economic characteristics of pupils or students and special educational needs, while the location of schools is also an important fact.

In 2001, Lithuania (Shewbridge, Godfrey, Hermann and Nusche, 2016) introduced formula-based funding of education in order to increase resource efficiency and quality in education. It is important that the distribution of funds is clearly distinguished between "tuition costs" (state grant) and "the expenditures for maintaining the institution" (local funds). This way of distribution makes it possible for the state to directly influence the quality of educational services.

In Estonia, the basic allocation mechanism (target grant for general education) is allocated by a funding formula that includes various indicators for the special educational needs of pupils and a weighting coefficient that takes into account the location of the school and the region (Santiago, Levitas, Radó and Shewbridge, 2016).

A key component of education reform in Ukraine is the implementation of the New Ukrainian School (NUS) reform (Filipchuk and Lomonosova, 2019). In 2019, 
changes were made to the formula regarding calculating the salaries of employees of inclusive resource centers, as well as the number of teachers' assistants increased, the division of classes into groups when studying individual subjects were taken into account, the estimated class size of urban communities in rural areas was reduced.

Effective management of financial resources at the educational level remains a huge problem in many schools. Monitoring and evaluating budget execution remain problematic with the widespread introduction of decentralization. Funds allocated for education from the state budget are significant in both developed and developing countries, so their effective distribution remains important. For Ukraine, which is at the initial stage of reforming the financing of the education system, the experience of foreign countries is important (Levačić and Downes, 2004). A comparative analysis of the models of financial support distribution of the educational process at the level of EIs in England and Poland is given in Table 1.

Table 1. Comparative analysis of models of financial support distribution of the educational process at the level of EIs in England and Poland

\begin{tabular}{|c|c|c|}
\hline & England & Poland \\
\hline $\begin{array}{l}\text { Financing } \\
\text { system }\end{array}$ & $\begin{array}{l}\text { State funding }-75 \% \text { from local } \\
\text { budgets, the rest - local taxes. }\end{array}$ & $\begin{array}{l}\text { Highly decentralized: primary } \\
\text { education is financed from local } \\
\text { budgets, secondary - from state budget }\end{array}$ \\
\hline $\begin{array}{l}\text { The formula } \\
\text { for financing } \\
\text { an EI }\end{array}$ & $\begin{array}{l}\text { The formula of fair funding - } \\
\text { among EIs, funds are distributed } \\
\text { mainly according to the number of } \\
\text { new students, according to age. }\end{array}$ & $\begin{array}{l}\text { Use } 2 \text { financing methods: on the basis } \\
\text { of vouchers issued to parents with the } \\
\text { declared amount of funds for } \\
\text { education; based on the actual number } \\
\text { of new students. }\end{array}$ \\
\hline Management & $\begin{array}{l}\text { Local Management of Schools - } \\
\text { elected at the School Forum. }\end{array}$ & Directorate and Accounting Service. \\
\hline Transparency & $\begin{array}{l}\text { Open information about the amount } \\
\text { of funding for a particular school; } \\
\text { high involvement in the process of } \\
\text { distribution of funds - authorized } \\
\text { people, school administration, } \\
\text { parents, community. }\end{array}$ & $\begin{array}{l}\text { Open information concerning the } \\
\text { amount of funding for an individual } \\
\text { school or allocations for education in } \\
\text { general; not high involvement of } \\
\text { stakeholders in the transparency of the } \\
\text { distribution of funds. }\end{array}$ \\
\hline $\begin{array}{l}\text { Collection } \\
\text { and } \\
\text { verification of } \\
\text { information }\end{array}$ & $\begin{array}{l}\text { Form a detailed report on the cost } \\
\text { of funds, indicating the information } \\
\text { for each student in terms of his/her } \\
\text { needs and the corresponding results } \\
\text { in electronic form. The accuracy of } \\
\text { the information is checked by } \\
\text { selective audits }\end{array}$ & $\begin{array}{l}\text { Statistical reporting is formed on the } \\
\text { total number of students, according to } \\
\text { age, sex, special needs. There is no } \\
\text { general mechanism for verifying } \\
\text { statistical information, so there are } \\
\text { high risks of inaccuracies. }\end{array}$ \\
\hline $\begin{array}{l}\text { Financial } \\
\text { control at the } \\
\text { level of the EI }\end{array}$ & $\begin{array}{l}\text { Introduction of the Unified System } \\
\text { of Financial Reporting (Consistent } \\
\text { financial reporting), which made it }\end{array}$ & $\begin{array}{l}\text { Using two accounting systems in } \\
\text { parallel: } \\
\text { - ZEAS (Centralized Accounting Unit) }\end{array}$ \\
\hline
\end{tabular}




\begin{tabular}{|l|l|l|l|} 
& $\begin{array}{l}\text { possible to use unified codes for } \\
\text { revenues and expenditures of all } \\
\text { EIs. This has greatly facilitated } \\
\text { comparisons and audits of EIs. }\end{array}$ & $\begin{array}{l}\text { applies to the system of all EIs; } \\
\text { "Decentralized accounting" is } \\
\text { introduced separately at the level of a } \\
\text { particular school. }\end{array}$ \\
\hline $\begin{array}{l}\text { Audit of } \\
\text { accounts and } \\
\text { operations }\end{array}$ & $\begin{array}{l}\text { Three-level audit: level of EI, } \\
\text { internal (local authorities), } \\
\text { external. }\end{array}$ & $\begin{array}{l}\text { Two-level audita local audits, } \\
\text { conducted regularly by local } \\
\text { governments and regional audits, are } \\
\text { conducted selectively and irregularly. }\end{array}$ \\
\hline $\begin{array}{l}\text { Identification } \\
\text { of } \\
\text { weaknesses }\end{array}$ & $\begin{array}{l}\text { Accounting for unofficial funds } \\
\text { (donations and charitable } \\
\text { contributions) that do not fall under } \\
\text { state audit. }\end{array}$ & $\begin{array}{l}\text { Violation of the rules of tender } \\
\text { procedures; remuneration for } \\
\text { almission to the EI; salaries to } \\
\text { teachers who did not conduct classes; } \\
\text { appropriation of school equipment. }\end{array}$ \\
\hline
\end{tabular}

Source: Own study.

As we can see, the introduction of financing education is not a panacea, because such a model of financing and decentralization of the financial process may create risks of misuse of funds and corruption, but these risks are not greater than if the process is regulated by government agencies. On the other hand, formula funding has the effect of reducing the probability of these weaknesses due to public access to financial information. The transparency of the system forces a responsible attitude to the distribution and use of finances of responsible people. It reduces unpleasant consequences of identifying and publicizing possible abuses. Simpler formulas are clearer and, therefore, more transparent. However, too simple formula may be ineffective, as it does not differentiate sufficiently EIs by different structural cost factors. The considered examples indicate that the formation of the formula of financing and management of school finances is significantly influenced by the historical background and institutional environment, which must be taken into account.

The basic factors influencing the level of the distribution efficiency of funding for the educational process of the studied countries include: the formation of an adequate and effective formula for financing education, planning expenditures in accordance with educational policy, decentralization of education management, control and accountability. Taking into account the international experience, it became possible to form an improved model of a decentralized management system for financial and economic support of the educational process (Figure 1).

\section{Discussion and Conclusions}

The largest share of funding from national budgets falls at primary and secondary education in the world. It should be noted that countries with higher incomes spend a larger share of GDP on education, while expenditures in relation to total budget expenditures do not maintain this trend. Against the background of the studied countries, Ukraine, which is characterized by a fairly low level of income, spends 
the largest share of GDP on education, about 6-7\%, while the average value among EU countries - a little more than $3 \%$.

Figure 3. Model of decentralized management system of financial and economic support of the educational process

$\begin{aligned} & \text { Ministry of } \\ & \text { Education }\end{aligned} \mid \begin{aligned} & \text { - Formation of national policy. } \\ & \text { - Formation of quality standards of educational services. } \\ & \text { - Formation of financial support tools. } \\ & \text { - Powers to suspend funding and liquidation of the educational } \\ & \text { institution. }\end{aligned}$
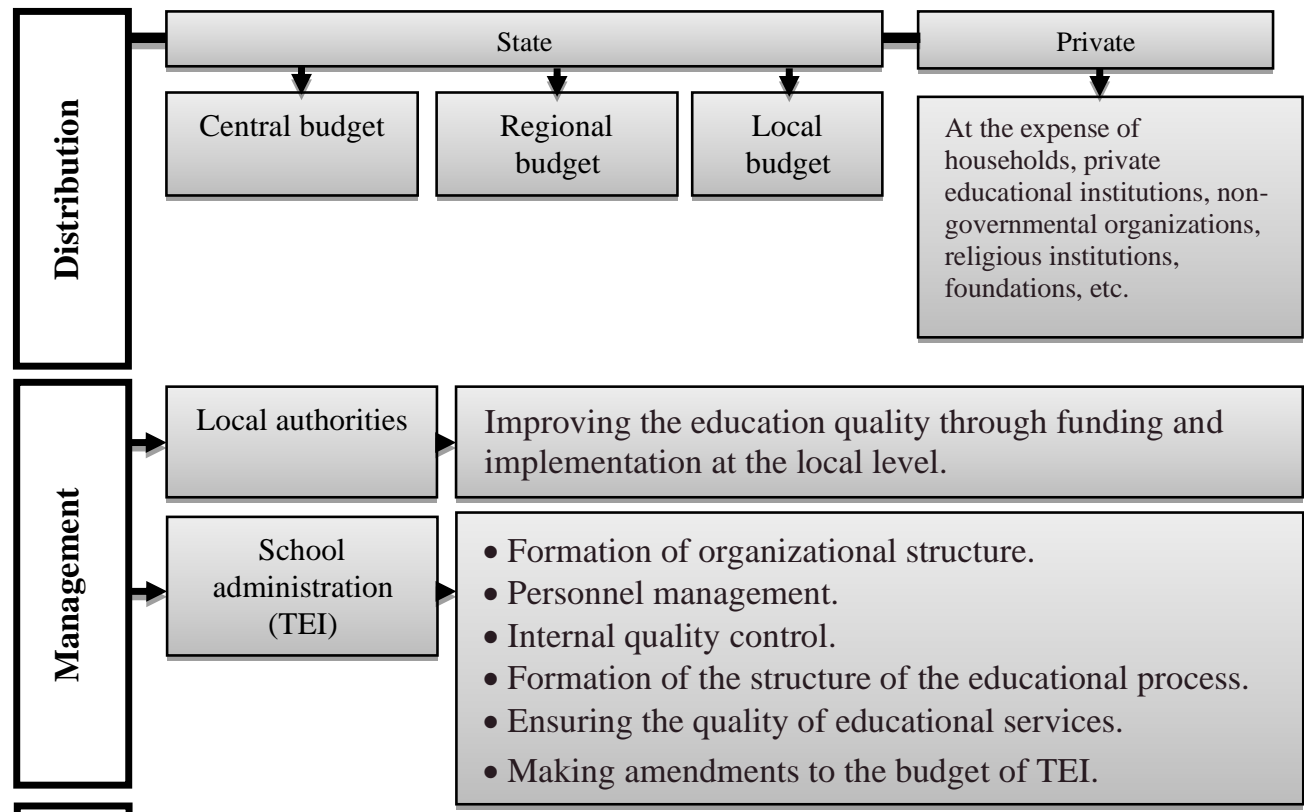

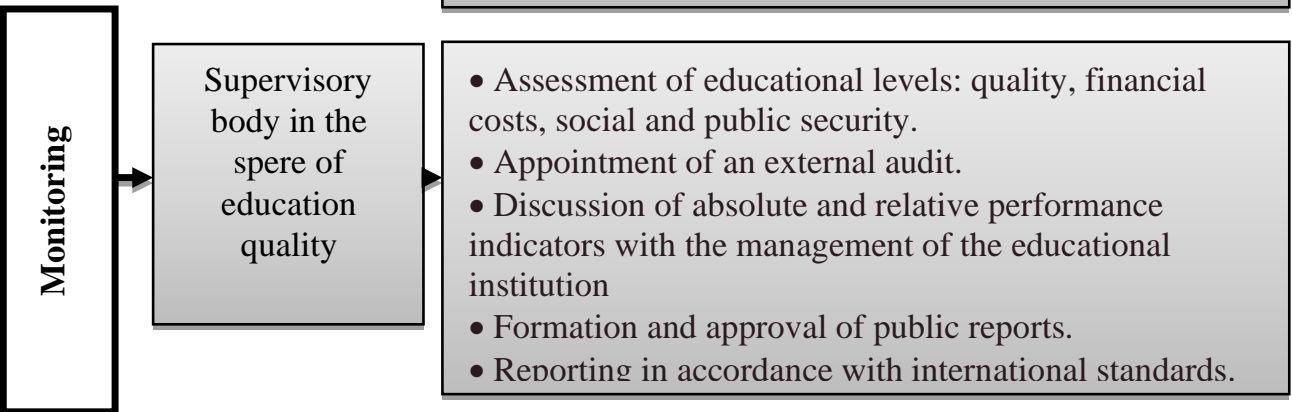

Source: Own study. 
However, the efficiency of the use and distribution of funds for educational services in Ukraine is quite low; this is evidenced by the indicator of calculating the level of funding for education per 1 pupil, which is the lowest in comparison with the studied countries.

Harmonized Indicator of the level of education is another qualitative indicator of the effectiveness of the funds' use at primary school. Despite significant gaps in the effectiveness of primary school funding, the level of education quality in Ukraine is quite good (478), it is between Greece and Bulgaria in the ranking of countries.

After studying the experience of forming the financial and economic system of education in different countries, we can conclude that the interconnection between the education expenditures and its results, or quality is not directly proportional. Estonia, with expenditures on primary and secondary education below the average EU and OECD indicators, has taken one of the leading positions in the quality of knowledge among European countries. About $90 \%$ expenditures on school education come from government sources in both Ukraine and EU countries under study, while higher education is to a greater extent funded by the private sector.

Taking this into consideration, governments are increasingly focusing on improving the allocation of funds to EIs, given the trend of declining funding for education, improving resource efficiency, and improving transparency, accountability and community participation.

The proposed model of decentralized management system of financial and economic support of the education system is designed to ensure the distribution of funds in a transparent and predictable manner. The introduction of expenditure planning for primary education at all levels will enable EIs to plan their development for the coming years. In addition, further research is needed to find new, innovative methods of financing the system of education.

\section{References:}

Barro, R.J. 1991. Economic Growth in a Cross Section of Countries. The Quarterly Journal of Economics, 2, 407-443.

Bellinger, A., Terway, A., Burnett, N. 2016. Innovative financing recommendations: International commission on global education financing. Results for Development. Washington, D.C.

Burnett, N., Bermingham, D. 2010. Innovative financing recommendations: International commission on global education financing. Results for Development. Washington, D.C.

De Witte, K., López-Torres, L. 2017. Efficiency in education: A review of literature and a way forward. Journal of the Operational Research Society, 68(4), 339-363. https://doi.org/10.1057/jors.2015.92. 
European Commission/EACEA/Eurydice. 2014. Financing schools in Europe: Mechanisms, methods and criteria in public funding. Eurydice Report. Publications Office of the European Union, Luxembourg.

Filipchuk, L., Lomonosova, N. 2019. Education and science budget 2019. CEDOS. Available at: https://cedos.org.ua/uk/articles/biudzhet-osvity-ta-nauky2019? fbclid=IwAR1tLRnCiHOeTvCW5XcHNDbgzZBikVTYA5TefIXTjxyHuIGkrl NrGrlqqCE.

Hausmann, R., Rodrik, D., Velasco, F. 2006. Getting the diagnosis right: A New approach to economic reform. Finance and Development, 43(1). Available at: https://www.imf.org/external/pubs/ft/fandd/2006/03/hausmann.htm.

Lee, J.W. 1995. Capital goods imports and long-run growth. Journal of Development Economics, 48, 91-110.

Levačić, R. 2008. Financing schools: Evolving patterns of autonomy and control. Educational Management Administration \& Leadership, 36(2), 221-234. https://doi.org/10.1177/1741143207087774.

Levačić, R., Downes, P. 2004. Formula funding of schools, decentralisation and corraption: a comparative analysis. International Institute for Educational Planning, Paris, France.

Mankiw, N.G., Romer, D., Weil, D. 1992. A contribution to the empiric of economic growth. Quarterly Journal of Economics, 107, 407-437.

Nusche, D., Miron, G., Santiago, P., Teese, R. 2015. OECD Reviews of School Resources: Flemish Community of Belgium 2015. OECD Publishing, Paris, France. https://doi.org/10.1787/9789264247598-en.

OECD. 2012. Equity and quality in education: Supporting disadvantaged students and schools. OECD Publishing, Paris, France. https://doi.org/10.1787/9789264130852-en.

OECD. 2017. The Funding of School Education: Connecting Resources and Learning. OECD Publishing, Paris, France. http://dx.doi.org/10.1787/9789264276147-en.

OECD. 2019. Education at a Glance 2019: OECD Indicators. OECD Publishing, Paris, France. https://doi.org/10.1787/f8d7880d-en.

Our World in Data. 2019. National average learning outcomes vs. Government expenditure per primary student. Available at: https://ourworldindata.org/grapher/nationalaverage-learning-outcomes-vs-government-expenditure-per-primary-student.

Santiago, P., Levitas, A., Radó, P., Shewbridge, C. 2016. OECD Reviews of School Resources: Estonia 2016. OECD Publishing, Paris, France. https://doi.org/10.1787/9789264251731-en.

Shewbridge, C., Godfrey, K., Hermann, Z., Nusche, D. 2016. OECD Reviews of School Resources: Lithuania 2016. OECD Publishing, Paris, France. https://doi.org/10.1787/9789264252547-en.

Stevens, P., Weale, M.W. 2003. Education and Economic Growth. Available at: http://cee.lse.ac.uk/conference_papers/28_11_2003/martin_weale.pdf.

Terway, A. 2017. Innovative financing for education: New actors and approaches. Available at: https://www.norrag.org/app/uploads/2017/12/PiE_Inaugural_SymposiumArushiTerwayInnovative_financing_for_education.pdf.

The World Bank. 2018. Analytical Report of educational State Policy: "Financial and budgetary sustainability of 'New Ukrainian school' implementation".

UNESCO. 2015. EFA global monitoring report - Education for All 2000-2015: Achievements and challenges. UNESCO, Paris, France.

United Nations. n./d. Millennium Development Goals. Available at: https://www.un.org/millenniumgoals/bkgd.shtml.

Winthrop, R. 2015. Global '100-Year Gap' in Education Standards. Brookings. 
Wolff, E.N. 2015. Educational expenditures and student performance among OECD countries. Structural Change and Economic Dynamics, 33(C), 37-57.

Wolff, E.N., Baumol, W.J., Saini, A.N. 2014. A comparative analysis of education costs and outcomes: The United States vs. other OECD countries. Economics of Education Review, 39, 1-21. https://doi.org/10.1016/j.econedurev.2013.12.002. 